\title{
Bridging School and Parents: Parental Involvement in their Child's Education
}

\author{
Suresh Kumar N Vellymalay \\ Universiti Sains Malaysia \\ E-mail: suresh@usm.my
}

Received: December 14

Accepted: December 28

Published: February 1, 2012

doi:10.5296/jse.v2i1.1170

URL: http://dx.doi.org/10.5296/jse.v2i1.1170

\begin{abstract}
This study was designed to identify the relationship between school-parents cooperation in enhancing Indian parents' involvement in their child's education. A hundred and fifty Indian students who were studying in National Type Tamil Schools in the district of Kerian, Perak Darul Ridzuan, Malaysia were randomly chosen based on stratified random sampling. The sample comprised 50 students from Year Three, 50 students from Year Four and 50 students from Year Five. Structured interviews were conducted with the respondents. Questionnaires were used by the researcher to obtain quantitative data related to the school-parents partnership and the parents' involvement strategies implemented for their child's education. The findings of this study indicate a moderate relationship in school-parents partnership in enhancing Indian parents' involvement in their child's education. The more the parents feel welcome at school, the higher their involvement in their child's education. The parents also show higher involvement when the school is cooperative in discussing their child. In addition, findings also indicate that parents are more involved in their child's education when the parents are kept informed about the meetings, activities and events that they have to attend.
\end{abstract}

Keywords: Parental involvement, Cooperation, Education, National Type Tamil School 


\section{Introduction}

Home and school are two different entities but there is a close association between each other (Lightfoot, 1978). In some schools, a clear isolation is seen between the school and family; and this affects the learning patterns of a child and also his or her development (Epstein, 1995). Some parents also display an interaction gap and relationship with their child's school.

One of the main causes of differences in the perception between the school and the parents is that the children especially from the working class fail to learn due to their unpleasant home environment (Ogbu, 1974). Apart from that, teachers also face problems with parents because parents are said to be not appreciative of the abilities and the skills of teachers, and they are unable to distinguish the importance between the relationship in the family and the relationship with the school (Lightfoot, 1978). It can be said here that the differences in the way the parents and the school view each other limits the parental involvement in their child's education (Smrekar and Cohen-Vogel, 2001). Hence, it is very important to explore the interaction and relationship between family and school during the child's early education as the learning pattern of a child will serve as a strong foundation for his or her behaviour, quality relationship and various types of parental involvement later (Lightfoot, 1978).

Many studies have proven that parents' background has a great influence on parental involvement in their child's education. In fact, parents' from a better socio-economic background or higher social class show greater involvement in ensuring their child's learning pattern and success at school. However, the influence of the parents' background should not be perceived as the only factor which enhances the academic success of a child. Parental involvement in the child's education also must be seen from various dimensions. One of them is the role of the school in encouraging parents' involvement in their child's education.

In this matter, as explained by Joyce Epstein (1995), one of the good approaches in describing the association between the school's role and parents' involvement is the partnership between the school, family and community. Epstein (1995) see parents' involvement in their child's education from the school's cooperation and family perspective in understanding the way school, family and community share their responsibility with students to ensure success in education. This is because, school, family or community does not necessarily contribute towards student's success; however activities resulting from school, family and community cooperation can direct and motivate student to achieve their own success (Epstein, 1995). Further to this, six types of involvement models drafted by Epstein (including Parenting, Communication, Voluntary involvement, Learning at home, Decision making and Cooperation with community) provide various opportunities for school, family and community to cooperate with one another. Furthermore, according to Epstein, while every type of involvement includes very practical forms of cooperation, there are various challenges in ensuring effective family involvement; and these will produce results which differ according to students, parents and school.

Hence, a school has a particular strategy that enables it to accomplish their school's vision and mission. Since all parents have high hopes on their children, they will cooperate with the school in whatever way to help in their children's education (Hildebrand, 1991)and 
therefore these six types of involvement can help create a cooperation programme that is effective in linking the school, family and community (Epstein, 1995).

According to Epstein (1995), the partnership between the school, family and community not only can improve the school environment and the programmes, but it also increases the parent's leadership and skill, linking parents with the school and community; in fact this type of partnership also helps with the teacher's task. Thus, Epstein explains that parent's involvement in their child's education from the perspective of the partnership between school and family in helps in understanding the ways school, family and community share their responsibility with students to ensure educational success. In accordance with that, the current study aims at explaining the school-parents partnership in terms of the relationship between the school's cooperation and parental involvement in their child's education.

\section{Review of Literature}

Many studies that have been conducted emphasize on parental involvement at home (Entewisle \& Hayduk, 1981; Lockheed, et al., 1989; Israel, et al., 2001; Ho-Sui Chu \& Willms, 1996; Baker \& Stevenson, 1986) and at school (Grolnick \& Slowiacek, 1994; Hill, 2001; Hill \& Craft, 2003; Lareau, 1987; Ramsay, et al., 1992; Reay, 2004; Baker \& Stevenson, 1986; Milne, et al., 1986; Epstein, 1995; Lareau, 1987) in providing a positive either at home or at school are often associated with the parent's background. Family background variables such as job, education, income, race and family structure feature prominently in studies related to the child's education (Milne, et. al., 1986: 125). In fact, the influences of family background on educational experience of a child become increasingly vital in the field of sociology of education (Lareau, 1987: 73).

The relationship between parents and school is inevitable whenever there is a discussion on the issue of formal education received by a child. The strength of parental involvement in their child's education increases when the school has positive views towards the parents; and if they are willing to collaborate with parents (Bauch \& Goldring, 2000; Griffith, 1998). To be more specific, in evaluating the relationship between parents and school, parental involvement in their child's education especially at school is truly important for a child's educational success during his or her school years. However, not all the parents are able give the same support to their children's education at school. In this case, family background has a significant influence on a child's achievement in education.

Lareau's study (1987), for example, found that middle-class parents view the partnership between parents and teachers as one of the factors which affects the child's educational success at school. Apart from Lareau (1987), Reay's study (1999) also found that apart from their experience dealing with the professionals, middle-class mothers bring in the habitus which is formed by educational success into the education space. Reay (2004) in another study on mother's involvement found that most middle-class mothers receive feedback from their child's school through dialogue sessions when conflicts arise between home and school and the mothers are also capable of rejecting irrational proposals at school.

Meanwhile, Baker and Stevenson’s (1986) study found that mothers who have a higher level 
of education have more knowledge on child's schooling, more contact with the school, are better informed about their child's achievement, monitor their child's progress and show more effort in leading their child to higher level of education (Baker and Stevenson, 1986). Apart from Baker and Stevenson's study, a study done by Ho Sui-Chu and Willms (1996) explains four major aspects of involvement practiced by parents in ensuring their child's educational success; and two of them are communication with the school and parental involvement at school. Ramsay's et al. (1992) study, on the other hand found that middle class parents engaged in school activities as they feel that their attendance is appreciated by the school. They also have more self confidence in their involvement and they have no feelings of inferiority when being involved in their child's education at school.

While the above studies have proved that parents have a high dependency on their child's school, a child's educational attainment does not always increase with the presence and the involvement indicated by parents solely at school (Allen, 2008). At the same time, the dependency between parents and the school should not only be observed as the relationship between parents and the school. It also must be observed as the relationship between school and the parents. This is an important issue that needs to be highlighted because parental involvement at school, as proven by the above studies, is definitely impossible without the direct involvement from the school.

Thus, the cooperation that is given by the school to the parents is undeniable in its importance in encouraging parents' involvement in their child's education regardless of whether it is at home or at school. This parental involvement could become more effective when there is good support and cooperation from the school. The support and the cooperation from the school could strengthen the parents' awareness about the importance of parental involvement in their child's education. The greater the support and the cooperation given by a school to parents, the higher the parental involvement that would be shown by those parents in their child's education.

Several studies have given emphasis to the relationship between the school's cooperation and parental involvement in their child's education. For example, according to Allen (2008), the role of the school, through their visit to the student's home not only creates a good relationship between both parties but it also enables the school to understand the student's learning patterns at home. This enables the school to strategize some plans to involve the parents in their child's education at home. Hindin's (2010) study, on the other hand, found that besides the effort taken by teachers to contact the parents through phone calls and letters, the communication between the school and the parents through arranged meetings, encourages the parents to be involved in their child's education at school.

Apart from that, Lloyd Smith and Baron's (2010) study identifies that the principals in small schools have more time and energy to support the efforts to involve parents in their child's education. In contrast to this, the principals in bigger schools have more staff and students to be assessed; and this involves time constraints and energy. Similarly, Bartel (2010) found that the school's cooperation encourages more parents to be involved in their child's education at home and at school. Zhao and Akiba's (2009) study, on the other hand, found that students 
achieve good results in certain subjects when the school principal has high hopes on the parents to support their child's education at home. This support includes the parents' behaviour in ensuring their children complete their homework as well as the parents' behaviour in communicating with the school the problems that are caused by their child at home.

The literature review discussed above clearly indicates that there is a significant relationship between the cooperation given by the school to parents and the parents' awareness of being involved in their child's education at school. However, in the Malaysian context, the number of studies that give priority to evaluating the school's cooperation in nurturing parents' awareness to be involved in their child's education is still very limited.

\section{Research Methods}

\subsection{Sample}

The sample of this study was drawn from the National Type Tamil Schools in the Kerian district located in the state of Perak Darul Ridzuan, Malaysia. A hundred and fifty students from a total of 194 Indian students studying in National Type Tamil Schools were randomly chosen based on stratified random sampling. The sample comprised 50 students from Year Three, 50 students from Year Four and 50 students from Year Five. Students in Year One and Year Two were not selected for this study as this group was at an early stage of schooling and it would be too early to monitor the involvement of their parents in their education. Year Six students were not chosen because the Ministry of Education does not permit any studies to be conducted on students sitting for the Year Six examination (Ujian Penilaian Sekolah Rendah). The students selected for this study were of Indian ethnicity.

From the 150 students who were chosen based on stratified random sampling, one parent for each student was selected (according to the student's view about the individual who spends the most time being involved in their education) to be the respondent for this study. This will provide an explanation about the school's cooperation and parental involvement in their children's education among these National Type Tamil Schools students in the district of Kerian.

\subsection{Instrument}

Structured interviews were conducted with the respondents. Questionnaires were used by the researcher to obtain quantitative data from the selected parents. Questions were adapted from Walker, et al., (2005). However, the researcher has modified the structure of the question according to the objective of the current study and made some changes in its response format. In this study, the questionnaire was divided into three parts, that is, parent's background, school's cooperation and parental involvement.

The first part of the questionnaire contained close-ended questions which were related to parent's background such as gender, age, home, level of education, occupation, income and household income. The second part of the questionnaire was related to the school's cooperation. There were six questions which measured the cooperation shown by the school to the parents. The final part of the questionnaire was a set of fourteen questions on parental involvement in their child's education.

\subsection{Method}

Structured interviews were conducted with the respondents. Structured interviews were 
carried out in their child's school. Each respondent who was engaged in the structured interview was informed that all the information provided by the respondent during the interview session would be kept confidential. Questionnaires that contained questions on parent's background, school's cooperation and the parental involvement in their child's education were used by the researcher to obtain quantitative data from the respondents. For each question, the respondents were asked to state whether they 'strongly agree', 'agree', 'agree /disagree', 'disagree' or 'strongly disagree' for each strategy regarding the parents' involvement in their child's education. Each structured interview using the questionnaire took approximately 20-30 minutes. The structured interview was conducted by the researcher himself.

All the information gathered from the respondents was analyzed using Statistical Package of Social Sciences (SPSS). All six items in the category of 'school's cooperation' were consistent. The Cronbach's alpha measure was 0.86 which indicates that the measure of these items was reliable. Moreover, the fourteen item scale in the category of 'parental involvement' was also internally consistent. The Cronbach's alpha measure was 0.93 which indicates that the measure of these items was reliable.

\section{Findings}

Table 1 presents the background of the parents in this study. The analysis shows that $79.3 \%$ of the parents studied are female. This justifies that mothers are more involved with their children and spend more time with them in helping with their children's education. Mothers tend to hold big responsibility in helping with their child's education compared to fathers (20.7\%). 


\section{Macrothink}

Table 1. Background of the respondents

\begin{tabular}{|c|c|c|}
\hline \multicolumn{2}{|c|}{ Background of the respondents } & Percentage (\%) \\
\hline $\begin{array}{l}\text { Gender } \\
\text { Age } \\
\text { Home } \\
\text { Level of education } \\
\text { Occupation } \\
\text { Income } \\
\text { Household income }\end{array}$ & $\begin{array}{l}\text { Male } \\
\text { Female } \\
\quad 30 \text { years and below } \\
31 \text { - } 40 \text { years } \\
\quad 41 \text { - } 50 \text { years } \\
\quad 51 \text { - } 60 \text { years } \\
\quad \text { Urban } \\
\text { Rural } \\
\text { No formal education } \\
\text { Completed primary education } \\
\text { Did not complete secondary } \\
\text { education } \\
\text { Completed } \\
\text { education } \\
\text { Certificate/Diploma holders } \\
\text { First Degree holders } \\
\text { Professional and technical } \\
\text { Administration and clerical } \\
\text { Service } \\
\text { Business } \\
\text { Labour } \\
\text { Not working (Housewives) } \\
\text { None } \\
\text { RM1000 and below } \\
\text { RM1001 - RM2000 } \\
\text { RM2001 - RM3000 } \\
\text { RM1000 and below } \\
\text { RM1001 - RM2000 } \\
\text { RM2001 - RM3000 } \\
\text { RM3001 - RM4000 }\end{array}$ & $\begin{array}{l}20.7 \\
79.3 \\
11.3 \\
57.3 \\
27.3 \\
4.0 \\
54.0 \\
46.0 \\
12.0 \\
27.3 \\
26.7 \\
32.0 \\
1.3 \\
0.7 \\
2.0 \\
2.0 \\
0.7 \\
5.3 \\
45.3 \\
44.7 \\
44.7 \\
48.7 \\
6.0 \\
0.7 \\
74.7 \\
20.7 \\
2.7 \\
2.0\end{array}$ \\
\hline
\end{tabular}

$\mathrm{n}=150$

As can be seen from Table 1, more than $80.0 \%$ of the parents are aged between 31-50 years. From this percentage, more than $50.0 \%$ of the parents are between $31-40$ years of age. The percentage of parents aged between $31-40$ years is $57.3 \%$. Furthermore, the percentage of parents aged between $41-50$ years is $27.3 \%$. The results also indicate that $54.0 \%$ of the parents are from the urban areas while $46.0 \%$ are from the rural areas. The reason for this is that the distribution of the Indian ethnic group in this district is more or less similar in both urban and rural areas, which enables the respondents to send their children to the school located nearby to their homes. 
The analysis in Table 1 indicates that $32.0 \%$ of the parents completed secondary education while $26.7 \%$ of the parents managed to go to secondary school but did not complete their secondary education. Meanwhile, about $27.3 \%$ of the parents only completed primary education and $12.0 \%$ of the parents never went to school. Only $2.0 \%$ of the parents in this study completed their tertiary education. As can be seen from the table above, more than 95.0\% of the parents have no professional qualifications. Moreover, it is apparent from this table that even though $32.0 \%$ parents completed their secondary education, there was no evidence that they had passed their Sijil Pelajaran Malaysia (a mandatory public examination for Form Five students).

In terms of occupation, most parents in this study work as labourers. Generally, the parents work in rubber plantations, oil-palm estates and in factories. Only $10.0 \%$ of the parents work in the four main fields, and these are professional and technical, administration and clerical, service and business sectors. Parent's education level does play an important role in ensuring a better occupation. Parents with a higher level of education especially those who possess a certificate, diploma or a first degree are in a better position to have a stable job. The other $44.7 \%$ of the respondents studied are housewives.

According to Table 1, 48.7\% of the parents studied earned a total income of RM1000.00 and below a month. Another 6.7\% of the parents earn between RM1001.00-RM3000.00 a month. However, none of the parents earn an income of more than RM3000.00 a month. In addition, $44.7 \%$ of the parents in this study have no income since they are housewives.

The findings of this study also show that the household income of the parents studied is not high. As shown in Table 1, 74.7\% of the parent's household income is between RM1000.00 and below. On the other hand, $20.7 \%$ of the parent's household income is between RM1001.00-RM2000.00. Only 4.7\% of the parent's household income is between RM2001.00-RM4000.00. It is very clear that almost $75.0 \%$ of the parents in this study are undergoing a difficult time with a household income of RM1000.00 and below. One of the main reasons is that $44.7 \%$ of the parents studied are housewives and they are entirely dependent on their husband's income and the income generated by their children who are between 31-50 years and the parents categorized in this age group tend to have more children who are still schooling compared to those parents whose children are working. Hence, the contribution from the life partner and the children has less impact on their household income.

Apart from the the importance given to the background of the parents, this study also identifies the cooperation given by the school in encouraging parent's involvement in their child's education. For the purpose of this study, the school's cooperation refers to school matters that the parents need to be informed of so that their involvement in supporting their child's learning patterns and educational success is much appreciated. The communication and the interaction between the school and family in the early years of a child's schooling lays a strong foundation for a solid behaviour, relationship and various types of parental involvement in later years (Lightfoot, 1978). 


\section{Macrothink}

Table 2. School's cooperation in encouraging parental involvement

\begin{tabular}{|l|l|l|l|l|l|}
\hline Strategy & $\begin{array}{l}\text { Strongly } \\
\text { Disagree } \\
(\%)\end{array}$ & $\begin{array}{l}\text { Disagree } \\
(\%)\end{array}$ & $\begin{array}{l}\text { Disagree } \\
\text { Agree } \\
(\%)\end{array}$ & $\begin{array}{l}\text { Agree } \\
(\%)\end{array}$ & $\begin{array}{l}\text { Strongly } \\
\text { Agree } \\
(\%)\end{array}$ \\
\hline Appreciate Attendance & 1.3 & 2.0 & 8.0 & 42.7 & 46.0 \\
Attention and Support & 1.3 & 3.3 & 10.7 & 37.3 & 47.3 \\
Notification of Meetings and & 3.3 & 2.0 & 5.3 & 35.3 & 54.0 \\
Activities & 6.7 & 12.7 & 18.0 & 37.3 & 25.3 \\
Suitability of Activity Hours & 6.0 & 8.7 & 14.7 & 26.0 & 44.7 \\
Notification of Child's & 6.0 & 7.3 & 16.7 & 34.7 & 35.3 \\
Problems of Child's & & & & & \\
Notification & & & & & \\
Progress & & & & \\
\hline
\end{tabular}

$\mathrm{n}=150$

As can be seen from Table 2, the centralization of parents' responses on 'Strongly Agree' and 'Agree' for every item listed in the category of 'school's cooperation indicates that cooperation given by the school to the parents is very encouraging. Parents in this study feel that the school is very appreciative of their attendance at school (88.7\%), willingness to pay attention and their support in discussing their child's education (84.6\%), give notification of the meetings and activities that need to be attended (89.3\%), arrange school activities that fit their schedule (62.6\%), give notification about the child's problems in education (70.7\%) and also the child's progress in education (70.0\%). The strength of the cooperation provided by the school enables the parents to emphasize more on involvement in their child's education.

Besides the focus on the school's cooperation, this study also intends to explain the level of parental involment in their child's education. Parental involvement here refers to parent's action and behaviour in helping with their child's learning patterns at home and at school through various strategies. 
Table 3. Parental involvement strategies in children's education

\begin{tabular}{|l|l|l|l|l|l|}
\hline Strategy & $\begin{array}{l}\text { Strongly } \\
\text { Disagree } \\
(\%)\end{array}$ & $\begin{array}{l}\text { Disagree } \\
(\%)\end{array}$ & $\begin{array}{l}\text { Disagree } \\
\text { Agree } \\
(\%)\end{array}$ & / Agree & $\begin{array}{l}\text { Strongly } \\
\text { Agree } \\
(\%)\end{array}$ \\
\hline Discussion on future planning & 1.3 & 7.3 & 14.0 & 36.7 & 40.7 \\
Discussion on school activities & 2.0 & 6.7 & 13.3 & 33.3 & 44.7 \\
Identifying learning patterns & 2.7 & 12.7 & 20.7 & 30.7 & 33.3 \\
Identifying academic problems & 1.3 & 10.0 & 20.3 & 34.0 & 34.7 \\
at school & 2.0 & 6.7 & 16.0 & 31.3 & 44.0 \\
Identifying academic problems & 4.7 & 16.7 & 14.0 & 32.7 & 32.0 \\
at home & 4.7 & 12.0 & 25.3 & 28.7 & 29.3 \\
Assisting with homework & 3.3 & 7.3 & 18.0 & 37.3 & 34.0 \\
Identifying homework & 2.0 & 5.3 & 15.3 & 36.7 & 40.7 \\
Guidance for examination & 3.3 & 4.0 & 7.3 & 39.3 & 46.0 \\
Monitoring & 10.7 & 12.7 & 34.0 & 37.3 \\
performance at school & 4.3 & 22.0 & 17.3 & 23.3 & 32.7 \\
Motivation & 16.7 & 17.3 & 11.3 & 20.7 & 34.0 \\
Time limits & 2.0 & 11.3 & 14.7 & 24.7 & 47.3 \\
Getting reading materials & & & & & \\
Tuition & & & & \\
Monitoring activities & & & & \\
\hline
\end{tabular}

$\mathrm{n}=150$

As shown in Table 3, the parents' responses centred on the 'Strongly Agree' and 'Agree' scale for every item listed in the category of 'parental involvement'. This response shows that overall the parents in this study are aware of their responsibility and are highly involved in their child's education. This is clearly seen through their actions and behaviour in helping with their child's learning patterns at home and at school. The parents in this study

discuss their child's future with them (77.4\%), discuss their child's activities in school (78.0\%), identify the learning patterns of their child at school by communicating with the teachers (64.0\%) and identify the academic problems faced by their child in school (68.7\%).

Moreover, the parents also show high involvement in identifying problems faced by his or her child in the learning process at home (75.3\%), help their child with school homework if the child encounters difficulties in completing it (64.7\%) and identify their child's homework given by the school (58.0\%). Furthermore, the parents also provide time limits for their children's activities including studying, watching television and other personal activities (71.3\%), provide additional reading materials (such as newspapers and magazines) to allow the child to get more information that may help them in their learning and thus improve their academic achievement. (56.0\%), provide tuition for their child to improve their educational achievement (54.7\%) and monitor their child's behaviour in other activities besides the regular activities at home and at school (72.0\%). The parents are also highly involved in guiding their children in their preparation for school examinations (71.3\%), monitor their 
child's academic performance at school from time to time based on their child's achievement in examinations (77.4\%) and motivate their child to achieve academic success (85.3\%).

Table 4 shows the correlation analysis between the school's cooperation and parental involvement in their child's education. All six items in the category of 'school's cooperation' shows a significant and positive relationship on parental involvement in most of the variables studied. For the purpose of this analysis, only the variables which showed association 0.30 and above will be discussed.

Table 4. Correlation between school's cooperation and parental involvement in their child's education

\begin{tabular}{|l|l|l|l|l|l|l|}
\hline \multirow{2}{*}{ Parental Involvement } & \multicolumn{6}{|l|}{ School's Cooperation } \\
\cline { 2 - 8 } & $\begin{array}{l}\text { AA } \\
(r)\end{array}$ & $\begin{array}{l}\text { AS } \\
(r)\end{array}$ & $\begin{array}{l}\text { NMA } \\
(r)\end{array}$ & $\begin{array}{l}\text { SAH } \\
(r)\end{array}$ & $\begin{array}{l}\text { NCB } \\
(r)\end{array}$ & $\begin{array}{l}\text { NCG } \\
(r)\end{array}$ \\
\hline Discussion on future planning & $0.34^{* *}$ & $0.28^{* *}$ & $.024^{* *}$ & $0.22^{* *}$ & 0.08 & 0.13 \\
Discussion on school activities & $0.33^{* *}$ & $0.31^{* *}$ & $0.34^{* *}$ & $0.22^{* *}$ & 0.14 & 0.14 \\
Identifying learning patterns & $0.20^{*}$ & $0.22^{* *}$ & 0.16 & $0.27^{* *}$ & 0.15 & $0.20^{*}$ \\
Identifying academic problems at & $0.39^{* *}$ & $0.28^{* *}$ & $0.22^{* *}$ & $0.16^{*}$ & 0.04 & $0.16^{*}$ \\
school & $0.22^{* *}$ & $0.18^{*}$ & $0.21^{*}$ & $0.29^{* *}$ & 0.10 & 0.12 \\
Identifying academic problems at & $0.32^{* *}$ & $0.23^{* *}$ & $0.34^{* *}$ & $0.26^{* *}$ & $0.19^{*}$ & $0.22^{*}$ \\
home & $0.28^{* *}$ & $0.33^{* *}$ & $0.22^{* *}$ & $0.23^{* *}$ & 0.08 & 0.10 \\
Assisting with homework & $0.40^{* *}$ & $0.32^{* *}$ & $0.33^{* *}$ & $0.24^{* *}$ & $0.18^{*}$ & 0.14 \\
Identifying homework & $0.37^{* *}$ & $0.31^{* *}$ & $0.39^{* *}$ & $0.30^{* *}$ & $0.22^{* *}$ & $0.27^{* *}$ \\
Guidance for examination & $0.40^{* *}$ & $0.36^{* *}$ & $0.28^{* *}$ & $0.23^{* *}$ & 0.13 & $0.22^{*}$ \\
Monitoring academic performance at & $0.38^{* *}$ & $0.34^{* *}$ & $0.29^{* *}$ & $0.31^{* *}$ & 0.12 & $0.17^{*}$ \\
school & $0.26^{* *}$ & $0.21^{* *}$ & 0.16 & $0.18^{*}$ & 0.07 & $0.22^{* *}$ \\
Motivation & $0.21^{* *}$ & $0.22^{* *}$ & $0.24^{* *}$ & $0.27^{* *}$ & $0.18^{*}$ & $0.30^{* *}$ \\
Time limits & $0.43^{* *}$ & $0.37^{* *}$ & $0.37^{* *}$ & $0.39^{* *}$ & $0.23^{* *}$ & $0.35^{* *}$ \\
Getting reading materials & & & & & & \\
Tuition & & & & & & \\
Monitoring activities & & & & & & \\
\hline
\end{tabular}

$\mathrm{n}=150$

AA - Appreciate Attendance

AS - Attention and Support

NMA - Notification of Meetings and Activities

SAH - Suitability of Activity Hours

NCB - Notification of Child's Problems

NCG - Notification of Child's Progress

** Correlation significant at the level of 0.01 
* Correlation significant at the level of 0.05

The findings of this study indicate that the school's cooperation in the form of appreciation shown upon the parent's attendance at school encourages the parents to be more involved in their child's education (see Table 4). Appreciation of the parent's attendance at school encourages the parents to discuss their child's future with them $(r=0.34, p<0.01)$, discuss their child's activities in school in order to get an overview of the things done by their children in school $(\mathrm{r}=0.33, \mathrm{p}<0.01)$ and identify the academic problems faced by their child in school $(\mathrm{r}=0.39 \mathrm{p}<0.01)$. Apart from that, appreciation of the parent's attendance at school by the school also motivates the parents to guide their children in their preparation for the school examinations ( $\mathrm{r}=0.40, \mathrm{p}<0.01)$, and monitor their child's academic performance at school from time to time based on their child's achievement in examinations $(r=0.37, p<$ 0.01). Furthermore, the school's cooperation in this matter also encourages the parents not only to motivate their child to achieve academic success $(\mathrm{r}=0.40, \mathrm{p}<0.01$ ) but also to provide additional reading materials (such as newspapers and magazines) to allow the child to get more information that may help them in their learning and thus improve their academic achievement $(r=0.38, p<0.01)$. At the same time, this cooperation in a way helps the parents to monitor their child's behaviour in other activities besides the regular activities at home and at school $(\mathrm{r}=0.43, \mathrm{p}<0.01)$.

The findings of this study also indicate that the greater the attention and support given by the school to the parents, the higher the parental involvement in their child's education (see Table 4). The attention and support given by the school encourages the parents to discuss their child's activities in school $(r=0.34, \mathrm{p}<0.01)$, identify their child's homework given by the school $(r=0.33, p<0.01)$ and guide their children in their preparation for school examinations $(r=0.32, p<0.01)$. It also helps the parents to monitor their child's academic performance at school $(\mathrm{r}=0.31, \mathrm{p}<0.01)$, motivate their child to achieve academic success $(\mathrm{r}=0.36, \mathrm{p}<0.01)$ besides providing time limits for their children's activities including academic activities, entertainment and personal activities $(r=0.34, \mathrm{p}<0.01)$. Furthermore, parents also show their involvement in their child's education outside the home and at school $(r=0.37, p<0.01)$ when they receive greater attention and support from the school.

Based on Table 4, it is clear that the more the school notifies the parents about the meetings and activities that need to be attended by parents at school, the higher the parental involvement seen in discussing their child's activities in school ( $\mathrm{r}=0.34, \mathrm{p}<0.01)$, helping their child with school homework $(\mathrm{r}=0.34, \mathrm{p}<0.01)$ and guiding their children in their preparation for school examinations $(r=0.33, p<0.01)$. This also helps the parents to monitor their child's academic performance at school $(r=0.39, p<0.01)$ and their child's behaviour in other activities besides the regular activities at home and at school $(\mathrm{r}=0.37, \mathrm{p}<$ $0.01)$.

The findings also reveal that the greater the effort taken by school to hold activities that fit the parents' schedule, the more involved the parents tend to be in their child's education. The school's cooperation in this task influences the parents' efforts in monitoring their child's academic performance at school $(\mathrm{r}=0.30, \mathrm{p}<0.01)$, providing time limits for their children 
for academic activities, entertainment and personal activities $(r=0.31, p<0.01)$ besides monitoring the child's behaviour in other activities besides the regular activities at home and at school $(\mathrm{r}=0.39, \mathrm{p}<0.01)$.

Apart from several types of school's cooperation discussed above, the school also could influence the parent's involvement by notifying the parents of their child's progress. As can be seen from Table 4, the more the school notifies the parents about their child's progress, the higher the tendency for parental involvement in providing tuition for their child to improve their educational achievement $(\mathrm{r}=0.30, \mathrm{p}<0.01)$. The behaviour of the parents is also similar in monitoring the child's behaviour in other activities besides the regular activities at home and at school $(\mathrm{r}=0.35, \mathrm{p}<0.01)$ when the school takes greater effort to inform the parents about their child's progress.

In short, the school's cooperation plays an important role in involving parents in their child's education to a greater extent. The more a school cooperates with the parents, the greater would be the parental involvement which has the capability to enhance their child's educational success.

\section{Discussion}

Although many studies emphasize the parent's socio-economic background and their social class as the predisposing factor to the parent's involvement in their child's education, this study however, has revealed the importance of the school's cooperation and support in increasing parental involvement in their child's education. The findings of this study indicate that the greater the cooperation and support given to parents by a school, the higher would be the parent's involvement in their child's education at home and at school. Thus, the results were in agreement with Lareau (1987), Reay (2004), Baker and Stevenson (1986) and Ho Sui-Chu and Willms's (1996) study which support the idea that there is a significant relationship between the school's cooperation and parent's involvement in their child's education.

The cooperation given by the school to parents through their appreciation of the parent's attendance at school increases the level of parental involvement in their child's education. The appreciation shown by the school and the parents' feelings about their attendance being appreciated bridges the gap that exists between parents and the school. The strength in the relationship between parents and the school enables the parents to apply various strategies of involvement in their child's education both at home and at school. The findings support the previous research of Ramsay (1992) who found that the school's appreciation of parent's attendance at school is an important factor for parental involvement at school.

The attention and the support indicated by the school in discussing the child's education enable the parents to understand the role and responsibilities of the school. It also enables the parents to understand every effort of the school in improving the student's educational attainment. The findings of the current study are consistent with those of Bartel (2010) and Zhao and Akiba (2009) who found that the school's cooperation encourages the parents to engage in various strategies of involvement in their child's education. Apart from that, the 
attention and the support given by the school also increase the parent's trust on school. It enables parents to move further according to school's claims and demands. The school's behaviour in this issue stimulates the parents to evaluate their own capabilities and their need to assist in their child's education towards achieving the vision and mission of the school. This enables the parents to identify the agenda or activities that have been carried out by their child at school. As a result of the attention and support from the school, the parents could easily acquire the knowledge and understanding about the parent's responsibilities, child's disipline, time management and other academic and non-academic information needed by the parents to enhance their child's education success.

Apart from that, the school's notification to parents with regard to meetings and activities held in the school is another type of cooperation shown by the school. It enables the parents to identify the school's agendas and discuss the agendas which take place at school with their child. Besides that, it helps the parents to identify the level of their child's involvement in curricular and co-curricular activities. The school's notification to parents about meetings and activities also enables the parents to identify important dates in the school calendar (for example, school tests and examination dates) so that they could continue to guide their children on their preparation for school examinations.

Furthermore, the school's cooperation in holding activities at the right time allows flexibility for the parents to attend these activities. In school, meetings between parents and teachers enable the parents to obtain important information about school activities, the importance of parental involvement and the strategies that can be applied by parents to be involved in their child's education at home and at school. Thus, the findings of the current study are consistent with those of Hindin (2010) which explains that communication between parents and school through arranged meetings motivates the parent to enhance parental involvement in their child's education at school.

At the same time, parents have a greater awareness of the need to be involved in their child's education when the school provides more information about their child's educational development and potential. The information gained by the parents from the school is important for parents to determine whether their child needs additional tuition to improve himself / herself. It also helps the parents to monitor their child's behaviour in order to ensure that they are on the right track in terms of learning attitude and behaviour.

Based on the discussion above, the present findings support the argument of Epstein (1995) which shows that the support and cooperation from the school is important to stimulate parental involvement in their child's education. The findings of this study clearly show that the support and cooperation given by the school to the parents lead to various partnership programs that could be implemented in the effort to enhance the relationship between the school and the parents. As a result of this relationship, parents are able to hone their skills and their leadership so as to enable the parents to share the responsibilities together with the school in engaging in their child's education. Moreover, the parents are more exposed to various strategies of involvement at home and at school as a result of the effective cooperation between both parties to ensure the educational success of the child. 
However, the analysis in this study showed that the correlation (r) .3 is below moderate. There are two possible explanations for this result. A possible explanation for this may be due to the similarity of language (Tamil) used at home and the language used as the medium of instruction and interaction at school. Teachers and parents come from similar language and cultural backgrounds. Language is influential in determining parental involvement in their children's education at school. A good relationship that is built between home and school based on the similarity of the language serves as an opportunity for the parents to discuss and understand more about the importance of parental involvement and the strategies of involvement in their children's education from the school. This enables the parents to communicate more effectively with the teachers. It encourages the parents to involve in their children's education at home using various strategies of involvement.

Another possible explanation for this is, in general, all parents' places high importance in their children's education. Low level of education should not be a reason for them to neglect their roles and responsibilities in their children's education. In the current study, most of the parents were not highly educated or from highly occupational status. However, they could have high aspiration for their children and would seriously want their children to succeed in education. The parents obviously do not want their children to experience the hardship of life as they (parents) do now. Thus, to certain extent, the parents could have learnt to adopt the some parental involvement strategies on what they should do to support their children education.

The current study has its limitations. The study only focuses on the relationship between the school's cooperation and parental involvement in their child's education without taking into account the socio-economic background of those parents studied. Thus, future research should address the influence of the school's cooperation on parental involvement in their child's education with regards to the parent's socioeconomic status. Apart from that, a study that explores the relationship between the school and parents in terms of cooperation, need to be cut across various ethnic groups. A comparative study might reveal a different perspective on the impact of the school's attitude and behaviour on parents from the various ethnic groups inbeing engaged in child education. Furthermore, a comparative study in engaging home, school and community would also be more meaningful in evaluating the cooperation and the relationship between the school and the parents. Thus, further research is recommended within this scope to understand the importance of home, school and community partnership in strengthening parental involvement.

\section{References}

Allen, J. (2008). Family Partnerships that Count. Educational Leadership, 66(1) (September), 22-27.

Baker, D.P., \& Stevenson, D.L. (1986). Mothers' Strategies for Children's School Achievement: Managing the Transition to High School. Sociology of Education, 59(3), 156-166. http://dx.doi.org/10.2307/2112340

Bartel, V.B. (2010). Home and School Factors Impacting Parental Involvement in a Title I 
Elementary School. Journal of Research in Childhood Education, 24(3), 209-228. http://dx.doi.org/10.1080/02568543.2010.487401

Bauch, P.A., \& Goldring, E.B. (2000). Teacher Work Context and Parent Involvement in Urban High Schools of Choice. Educational Research and Evaluation, 6(1), 1-23. http://dx.doi.org/10.1076/1380-3611(200003)6:1;1-I;FT001

Entwisle, D.R., \& Hayduk, L.A. (1981). Academic Expectations and the School Attainment of Young Children. Sociology of Education, 54(1), 34-50. http://dx.doi.org/10.2307/2112511

Epstein, J.L. (1995). School/Family/Community Partnership: Caring for the Children We Share. Phi Delta Kappan, 76(9), 701-712.

Griffith, J. (1998). The Relation of School Structure and Social Environment to Parent Involvement in Elementary Schools. The Elementary School Journal, 99(1), 53-80. http://dx.doi.org/10.1086/461916

Hildebrand, V. (1991). Introduction to Early Childhood Education (6 $6^{\text {th }}$ Edition). New Jersey: Prentice Hall.

Hindin, A. (2010). Linking Home and School: Teacher Candidates' Beliefs and Experiences. The School Community Journal, 20(2), 73-90.

Ho Sui-Chu, E., \& Willms, J.D. (1996). Effects of Parental Involvement on Eight-Grade Achievement. Sociology of Education, 69(2), 126-141. http://dx.doi.org/10.2307/2112802

Israel, G.D., Beaulieu, L.J., \& Hartless, G. (2001). The Influence of Family and Community Social Capital on Educational Achievement. Rural Sociology, 66(1), 43-68. http://dx.doi.org/10.1111/j.1549-0831.2001.tb00054.x

Lareau, A. (1987). Social Class Differences in Family-School Relationships: The Importance of Cultural Capital. Sociology of Education, 60(2), 73-85. http://dx.doi.org/10.2307/2112583

Lightfoot, S.L. (1978). Worlds Apart. New York: Basic Books.

Lloyd-Smith, L., \& Baron, M. (2010). Beyond Conferences: Attitudes of High School Administrators Toward Parental Involvement in One Small Midwestern State. The School Community Journal, 20(2), 23-44.

Lockheed, M.E, Fuller, B., \& Nyirogo, R. (1989). Family Effects on Students Achievement in Thailand and Malawi. Sociology of Education, 62(4), 239-256. http://dx.doi.org/10.2307/2112829

Milne, A.M., Myers, D.E., Rosenthal, A.S., \& Ginsburg, A. (1986). Single Parents, Working Mothers, and the Educational Achievement of School Children. Sociology of Education, 59 (July), 125-139. http://dx.doi.org/10.2307/2112335

Ogbu, J.U. (1974). The Next Generation. New York: Academic Press.

Ramsay, P., Harold, B., Hawk, K., Marriot, R., \& Poskitt, J. (1992). Sharing Curriculum Decisions with Parents: an overview of the findings of Project C.R.R.I.S.P. New Zealand 
Journal of Educational Studies, 27(2), 167-181.

Reay, D. (1999). Making Contacts with Teachers: Habitus, Cultural Capital and Mothers Involvement in their Children's Primary Schooling. In Grenfell, M \& Kelly, M. (1999). Pierre Bourdieu: Language, Culture and Education. Theory into Practice. Germany: Peter Lang.

Reay, D. (2004). Education and Cultural Capital: The Implications of Changing Trends In $\begin{array}{lllll}\text { Education } \quad \text { Policies. } & \text { Cultural } & \text { T3-86. }\end{array}$ http://dx.doi.org/10.1080/0954896042000267161

Smrekar, C., \& Cohen-Vogel (2001). The Voices of Parents: Rethinking the Intersection of Family and School. Peabody Journal of Education, 76(2), 75-100. http://dx.doi.org/10.1207/S15327930pje7602_5

Walker, J.M.T., Wilkins, A.S., Dallaire, J.R., Sandler, H.M., \& Hoover-Dempsey, K. (2005). Parental Involvement: Model Revision through Scale Development. The Elementary School Journal, 106(2), 85-103. http://dx.doi.org/10.1086/499193

Zhao, H., \& Akiba, M. (2009). School Expectations for Parental Involvement and Student Mathematics Achievement: A Comparative Study of Middle Schools in the US and South Korea. Compare, 39(3), 411-428. http://dx.doi.org/10.1080/03057920701603347 